Review

\title{
Nuruddin Farah: Selected bibliography
}

\section{F. Fiona Moolla}

NOVELS

Early novels

Farah, Nuruddin. From a Crooked Rib. Heinemann, 1970. A Naked Needle. Heinemann, 1976.

\section{The trilogies}

Variations on the Theme of an African Dictatorship

Farah, Nuruddin. Close Sesame. Allison \& Busby, 1983 Sardines. Allison \& Busby, 1981. Sweet and Sour Milk. Allison \& Busby, 1979.

Blood in the Sun

Farah, Nuruddin. Gifts. Serif, 1993. Maps. Pantheon, 1986. Secrets. Arcade, 1998.

Past Imperfect

Farah, Nuruddin. Crossbones. Riverhead, 2011. Knots. Riverhead, 2007. Links. Gerald Duckworth, 2005.

In the Belly of the Gerenuk or Somalis, In Other Words (Provisional titles) Farah, Nuruddin. Hiding in Plain Sight. Riverhead-Penguin, 2014. North of Dawn. Riverhead, 2018.

\section{PLAYS}

The Offering is the only play by Farah that has been published to date.

Farah, Nuruddin. The Offering. Lotus (Afro-Asian Writings) vol. 30, no. 4, 1976, pp. 77-93.

\section{SHORT STORIES}

Farah, Nuruddin. "The Start of the Affair." The Picador Book of African Stories, edited by Stephen Gray. Picador, 2000, pp. 143-9.

"My Father, the Englishman, and I." Under African Skies: Modern African Short Stories, edited by Charles R. Larson. Farrar, Strauss \& Giroux, 1997. "Why Dead So Soon." Somali News, 1965.

\section{NONFICTION}

Farah, Nuruddin. Yesterday, Tomorrow: Voices from the Somali Diaspora. Cassell, 2000.

F. Fiona Moolla is associate professor in the English Department, University of the Western Cape, Bellville, South Africa. She is the author of Reading Nuruddin Farah: The Individual, the Novel \& the Idea of Home (James Currey, 2014).

Email: fmoolla@uwc.ac.za

(D) https://orcid.org/0000-0001-7809-2222

D0l: https://doi.org/10.17159/2309-9070/tvl.v.57il.8085 
ESSAYS

\section{Autobiographical and literary}

Farah, Nuruddin. "Celebrating Differences: The 1998 Neustadt Lecture." Emerging Perspectives on Nuruddin Farah, edited by Derek Wright. Africa World P, 2002, pp. 15-24.

. "Childhood of My Schizophrenia." Times Literary Supplement, 23-29 Nov. 1990, p. 1264.

."ACountry in Exile."World LiteratureToday vol.72, no. 4,1998,pp. 713-5. DOI: https://doi.org/10.2307/40154257.

."The Creative Writer and the Politician." The Classic vol. 3, no. 1, 1984, pp. 27-30.

. "Do Fences Have Sides?" The Commonwealth in Canada: Proceedings of the Second Triennial Conference of CACLALS,

Part 2, edited by Uma Parameswaran, Writers' Workshop, 1983, pp. 174-82.

. "Do You Speak German?!" Okike: An African Journal of New Writing vol. 22, 1982, pp. 33-8.

"Germany - And All That Jazz." Okike: An African Journal of New Writing vol. 18, 1981, pp. 8-12.

. "Ibsen, In Other Words." Nordlit vol. 34, 2015, pp. 15-22. DOI: https://doi.org/10.7557/13.3350.

"In Praise of Exile." Literature in Exile, edited by John Glad. Duke U P, 1990, pp. 64-77.

"Savaging the Soul of a Nation." The Writer in Politics, edited by William Glass \& Lorin Cuoco. Southern Illinois U P, 1996, pp. 110-5.

"Why I Write." Emerging Perspectives on Nuruddin Farah, edited by Derek Wright. Africa World P, 2002, pp. $1-13$.

\section{Social and political}

Farah, Nuruddin. "Bastards of Empire." Transition vol. 65, 1995, pp. 26-35.

. "Centuries-long War for Somali Peninsula." WardheerNews. 12 Apr. 2018. wardheernews.com/centuries-longwar-for-somali-peninsula/.

. "Country Cousins." London Review of Books. 3 Sep. 1998, pp. 19-20.

"False Accounting." Granta vol. 49, 1994, pp. 171-81.

"My Life as a Diplomat." The New York Times. 26 May 2007. www.nytimes.com/2007/05/26/opinion/26farah. html.

"Of Tamarind and Cosmopolitanism." African Cities Reader, edited by Ntone Edjabe \& Edgar Pieterse. Chimurenga, 2010, pp. 178-81.

"People of a Half-Way House." London Review of Books. 21 Mar. 1996, pp. 19-20.

"Praise the Marines? I Suppose So." New York Times. 28 Dec. 1992, pp. 14-7.

"The Family House." Transition vol. 99, 2008, pp. 6-15.

"The Women of Kismayo." Times Literary Supplement. 15 Nov. 1996, p. 18.

"Which way to the Sea, Please?" Horn of Africa vol. 1, no. 4, 1978, pp. 31-6. Republished by WardheerNews. 4 Mar. 2015.

\section{INTERVIEWS}

\section{Published}

Alden, Patricia \& Louis Tremaine. "How Can We Talk of Democracy? An Interview with Nuruddin Farah." Emerging Perspectives on Nuruddin Farah, edited by Derek Wright. Africa World P, 2002, pp. 25-46.

Appiah, Kwame Anthony. "Nuruddin Farah." Bomb Magazine, 1 Apr. 2004. bombmagazine.org/articles/nuruddin$\underline{\text { farah/. }}$.

Farah, Nuruddin. "Nuruddin Farah and Binyavanga Wainana in Conversation." Rift Valley Forum's Nairobi Institute in partnership with Kwani Trust. www.youtube.com/watch?v=UbNk uztZ8s.

Garuba, Harry. "Nuruddin Farah: Long Road to Freedom." The Independent. 11 Mar. 2005.

"Dreaming on Behalf of the Community: A Conversation with Nuruddin Farah." Boundary 2 vol. 44, no. 2 , 2017, pp. 1-13. DOI: https://doi.org/10.1215/01903659-3826600.

Gray, Stephen. "Nuruddin Farah." Indaba: Interviews with African Writers, by Stephen Gray. Protea, 2005, pp. 179-92.

Jaggi, Maya. "A Combining of Gifts: An Interview.” Third World Quarterly vol. 11, no. 3, 1989, pp. 171-87.

Jonas, Maggie. "Farah—Living in a Country of the Mind." New African, Dec. 1987, pp. 60-1.

Jussawalla, Feroza F. \& Reed Way Dasenbrock. "Nuruddin Farah." Interviews with Writers of the Post-colonial World, edited by Feroza F. Jussawalla \& Reed Way Dasenbrock. U P of Mississippi, 1992, pp. 42-62. 
Moss, Robert. "Mapping the Psyche." West Africa. 1 Sep. 1986, pp. 1827-8.

Niemi, Minna. "Witnessing Contemporary Somalia from Abroad: An Interview with Nuruddin Farah." Callaloo vol. 35, no. 2, 2012, pp. 330-40. DOI: https://doi.org/10.1353/cal.2012.0056.

Pajalich, Armando. "Nuruddin Farah: Interviewed by Armando Pajalich." Kunapipi vol. 15, no. 1, 1993, pp. 61-71.

\section{YouTube videoclip interviews}

Boundary 2 journal. "Boundary 2 presents: A Reading and Conversation with Nuruddin Farah." YouTube. 28 Nov. 2018. www.youtube.com/watch? v=lngsh-3mnaU.

Campus TV India. "USOL $4^{\text {th }}$ Convocation address by world renowned author Prof. Nuruddin Farah." YouTube. 3 Apr. 2017. www.youtube.com/watch?v=DadfH6SD4hQ.

Detroit Public TV. "Nuruddin Farah on his novel, Hiding in Plain Sight in Miami." YouTube. 25 Nov. 2014. www. youtube.com/watch?v=HgEYggYOoIg.

ModernLitCollection. "Somalian writer Nuruddin Farah speaks at the International Writers Center conference, 'The Writer in Politics: Under Politics with a Politics', 20 Oct. 1992." YouTube. www.youtube.com/ watch? $=$ =ib3emyf4Les.

Rift Valley Institute. "Nuruddin Farah in conversation with Tom Odhiambo." YouTube. 14 May 2014. www. youtube.com/watch? $=$ WsPYiltC5OA.

"Nuruddin Farah in conversation with Binyavanga Wainaina." YouTube. 15 May 2013. www.youtube.com/ watch? $v=$ UbNk uztZ8s.

SOFHeyman. "Princeton Professor K. Anthony Appiah interviewed African novelist Nuruddin Farah about his recently released novel, 'Knots'." YouTube. 21 Feb. 2007. www.youtube.com/watch?v=jYlXh9hHK-E.

Somali Writers Collective. "Nuruddin Farah interview at the Commonwealth Club of California." YouTube. 24 Aug. 2010. www.youtube.com/watch?v=TM3DfxDQMFk.

The Loft Literary Centre. "Nuruddin Farah at the Loft." YouTube. 13 Nov. 2013. www.youtube.com/ watch?v=bTQIS3JFfZk.

UNICEF Innocenti. "Challenges for women $\&$ children in Somalia: Discussing education and conflict with Nuruddin Farah." YouTube. 24 Jan. 2014. www.youtube.com/watch?v=HBwf87W2CnM.

\section{CRITICISM}

\section{Monographs and edited volumes}

Alden, Patricia \& Louis Tremaine. Nuruddin Farah. Twayne, 1999.

Masterson, John. The Disorder of Things: A Foucauldian Approach to the Work of Nuruddin Farah. Wits U P, 2013.

Moolla, F. Fiona. Reading Nuruddin Farah: The Individual, the Novel and the Idea of Home. James Currey, 2014.

Wright, Derek. The Novels of Nuruddin Farah. Breitinger, 2004.

Wright, Derek, ed. Emerging Perspectives on Nuruddin Farah. Africa World P, 2002.

\section{Articles and chapters in books}

Adam, Ian. "The Murder of Soyaan Keynaan." Emerging Perspectives on Nuruddin Farah, edited by Derek Wright. Africa World P, 2002, 331-44.

"Nuruddin Farah and James Joyce: Some Issues of Intertextuality." World Literature Written in English vol. 24, no. 1, 1984, pp. 34-43. DOI: https://doi.org/10.1080/17449858408588868.

Ahmed, Ali Jimale. "The Arab Factor in Somali Culture: The Rise of the Novel in Somalia and Djibouti." Journal of Somali Studies vol. 1, no. 2, 2014, pp. 9-38.

Daybreak is Near: Literature, Clans and the Nation-state in Somalia. Red Sea, 1996.

Alden, Patricia. "New Women and Old Myths: Chinua Achebe's Anthills of the Savannah and Nuruddin Farah's Sardines." Emerging Perspectives on Nuruddin Farah, edited by Derek Wright. Africa World P, 2002, pp. 359-80.

Alden, Patricia \& Louis Tremaine. "Reinventing Family in the Second Trilogy of Nuruddin Farah." World Literature Today vol. 72, no. 4, 1998, pp. 759-66. DOI: https://doi.org/10.2307/40154267.

Alidou, Ousseina. "Boundaries of Fatherhood in Nuruddin Farah's Secrets." Emerging Perspectives on Nuruddin Farah, edited by Derek Wright. Africa World P, 2002, pp. 661-80. 
Alidou, Ousseina \& Alamin Mazrui. "Secrets: Farah's 'Things Fall Apart." Research in African Literatures vol. 31 no. 1, 2000, pp. 122-8. DOI: https://doi.org/10.1353/ral.2000.0002.

Andindilile, Michael. "English, Cosmopolitanism and the Myth of National Linguistic Homogeneity in Nuruddin Farah's Fiction." Forum for Modern LanguageStudies vol. 50, no. 3, 2014, pp. 256-74. DOI: https://doi.org/10.1093/ fmls/cqu025.

Appiah, Kwame Anthony. "For Nuruddin Farah." World Literature Today vol. 72, no. 4, 1998, pp. 703-5. DOI: https:// doi.org/10.2307/40154254.

Bardolph, Jacqueline. "Brothers and Sisters in Nuruddin Farah's Two Trilogies." World Literature Today vol. 72, no. 4, 1998, pp. 727-32. DOI: https://doi.org/10.2307/40154262.

"Dreams and Identity in the Novels of Nuruddin Farah." Research in African Literatures vol. 29 no. 1, 1998, pp. $163-73$.

. "On Nuruddin Farah." Research in African Literatures vol. 31, no. 1, 2000, pp. 119-21. DOI: https://doi.org/10.2979/ $\underline{\text { ral.2000.31.1.119. }}$.

"Time and History in Nuruddin Farah's Close Sesame." Emerging Perspectives on Nuruddin Farah, edited by Derek Wright. Africa World P, 2002, pp. 399-418.

Brown, Michelle Lynn. "Bleeding for the Mother (Land): Reading Testimonial Bodies in Nuruddin Farah's Maps." Research in African Literatures vol. 41, no. 4, 2010, pp. 125-43. DOI: https://doi.org/10.2979/ral.2010.41.4.125.

Bystrom, Kerry. "Humanitarianism, Responsibility, Links, Knots." Interventions: The International Journal of Postcolonial Studies vol. 16, no. 3, 2014, pp. 405-23. DOI: https://doi.org/10.1080/136980lx.2013.798141.

Caminero-Santangelo, Byron. "The Nature of African Environmentalism." Different Shades of Green: African Literature, Environmental Justice, and Political Ecology, by Byron Caminero-Santangelo. U of Virginia P, 2014, pp. 36-74.

Carbonieri, Divanize. "Please Do Not Judge Us Too Harshly!-The Exile's Return to Contemporary Somalia in Links by Nuruddin Farah." Acta Scientiarum: Language and Culture vol. 36, no. 1, 2014, pp. 83-91. DOI: https:// doi.org/10.4025/actascilangcult.v36il.19340.

Cheah, Peng. "Resisting Humanitarianization." A chapter on Gifts in What is a World? On Postcolonial Literature as World Literature." Duke U P, 2016, pp. 278-309.

Cingal, Guillaume. "Self and Identity in the Blood in the Sun Trilogy." Emerging Perspectives on Nuruddin Farah, edited by Derek Wright. Africa World P, 2002, pp. 431-48.

Cobham, Rhonda. "Misgendering the Nation: African Nationalist Fictions and Nuruddin Farah's Maps." Nationalisms and Sexualities, edited by Andrew Parker et al. Routledge, 1992, pp. 42-59.

Cochrane, Judith. "The Theme of Sacrifice in the Novels of Nuruddin Farah." World Literature Written in English vol. 18, 1979, pp. 69-77. DOI: https://doi.org/10.1080/17449857908588585.

Colmer, Rosemary. "Territories of Pain." International Literature in English: Essays on the Major Writers, edited by Robert L. Ross. St. James P, 1991, pp. 131-42.

“'This is a Pen': Writing in Maps." Emerging Perspectives on Nuruddin Farah, edited by Derek Wright. Africa World P, 2002, pp. 495-508.

Colson, Robert L. "The Performance of Madness as Resistance in Nuruddin Farah's Close Sesame." Ariel vol. 46, no. 4, 2015, pp. 1-36. DOI: https://doi.org/10.1353/ari.2015.0034.

Crowley, Dustin. "Cosmopolitan Somalia: Place and Identity in Farah's Maps and Links." Africa's Narrative Geographies: Charting the Intersections of Geocriticism and Postcolonial Cities, by Dustin Crowley. Palgrave Macmillan, 2015, pp. $101-28$.

Currey, James. "Publishing Nuruddin Farah." Africa Writes Back: The African Writer's Series and the Launch of African Literature, by James Currey. James Currey, 2008, pp. 154-68.

Dasenbrock, Reed Way. "Nuruddin Farah: A Tale of Two Trilogies." Emerging Perspectives on Nuruddin Farah, edited by Derek Wright. Africa World P, 2002, pp. 49-66.

Dhar, Tej N. "Manufacturing Skin for Somalia's History: Nuruddin Farah's Deep Hurt in Links." New Novels in African Literature Today: A Review. African Literature Today 27, edited by Ernest N. Emenyonu. James Currey, 2010, pp. 103-16.

Dietche, Julie Phelps. "Alas, No Answer: Structure as Theme in Nuruddin Farah's Maps." Emerging Perspectives on Nuruddin Farah, edited by Derek Wright. Africa World P, 2002, pp. 545-58.

Dodgson-Katiyo, Pauline. "The 'Rubble' \& the 'Secret Sorrows': Returning to Somalia in Nuruddin Farah's Links and Crossbones." African Literature Today vol. 34, 2016, pp. 67-81. 
Eldridge, Michael. "Out of the Closet: Farah's Secrets." Emerging Perspectives on Nuruddin Farah, edited by Derek Wright. Africa World P, 2002, pp. 637-60.

Eruvbetine, A. E. \& Solomon Omatsola Azumurana. "Melancholia and the Search for the Lost Object in Farah's Maps." Tydskrifvir Letterkunde vol. 54, no. 1, 2017, pp. 142-57. DOI: https://doi.org/10.17159/tvl.v.54il.9.

Ewen, D. R. "Nuruddin Farah." The Writing of East and Central Africa, edited by G. D. Killam. Heinemann, 1984, pp. 192-210.

Gagiano, Annie. "Appreciating Nuruddin Farah's Secrets." English Academy Review vol. 16, 1999, pp. 91-100. DOI: https://doi.org/10.1080/10131752.1999.10384460.

. "Farah's Sardines: Women in a Context of Despotism." Africa Today vol. 57, no. 3, 20ll, pp. 3-20. DOI: https:// doi.org/10.2979/africatoday.57.3.3.

"Farah's Sweet and Sour Milk: The Noise in the Dictator's Ear." Dealing with Evils: Essays on Writing from Africa, $2^{\text {nd }}$ ed., by Annie Gagiano. Ibidem, 2014, pp. 225-47.

"Surveying the Contours of 'a Country in Exile': Nuruddin Farah's Somalia." African Identities vol. 4, no. 2, 2006, pp. 25l-68. DOI: https://doi.org/10.1080/14725840600761195.

Garuba, Harry. "Mapping the Land/Body/Subject: Colonial and Postcolonial Geographies in African Narrative." Alternation vol. 9, no. 1, 2002, pp. 87-116.

"No-Man's Land: Nuruddin Farah's Links and the Space of Postcolonial Alienation." Literary Landscapes: From Modernism to Postcolonialism, edited by Attie de Lange, Gail Fincham, Jeremy Hawthorn \& Jakob Lothe. Palgrave Macmillan, 2008, pp. 180-97.

"Teacherly Texts: Imagining Futures in Nuruddin Farah's Past Imperfect Trilogy." Boundary 2 vol. 44, no. 2 , 2017, pp. 15-30. DOI: https://doi.org/10.1215/01903659-3826609.

Gikandi, Simon. "Nuruddin Farah and Postcolonial Textuality." World Literature Today vol. 72, no. 4, 1998, pp. 7538. DOI: https://doi.org/10.2307/40154266.

"The Politics and Poetics of National Formation: Recent African Writing and Maps." Emerging Perspectives on Nuruddin Farah, edited by Derek Wright. Africa World P, 2002, pp. 449-68.

Gorlier, Claudio. "Mystery and Madness in Close Sesame." Emerging Perspectives on Nuruddin Farah, edited by Derek Wright. Africa World P, 2002, pp. 419-30.

"Nuruddin Farah's Italian Domain." World Literature Today vol. 72, no. 4, 1998, pp. 781-5. DOI: https://doi. org $10.2307 / 40154270$.

Gugler, Josef. "African Literary Comment on Dictators: Wole Soyinka's Plays and Nuruddin Farah's Novels." Journal of Modern African Studies vol. 26, no. 1, 1988, pp. 171-7. DOI: https://doi.org/10.1017/s0022278x00010405.

Gurnah, Abdulrazak. "Nuruddin Farah's Gifts." Emerging Perspectives on Nuruddin Farah, edited by Derek Wright. Africa World P, 2002, pp. 611-4.

Hand, Felicity. "Negotiating Boundaries in the Horn of Africa: Women in the Fiction of Nuruddin Farah." Borderlands: Negotiating Boundaries in Post-Colonial Writing, edited by Monika Reif-Hulser. Rodopi, 1999, pp. $115-22$.

Hawley, John C. "Nuruddin Farah: Tribalism, Orality and Postcolonial Ultimate Reality and Meaning in Contemporary Somalia." Emerging Perspectives on Nuruddin Farah, edited by Derek Wright. Africa World P, 2002, pp. 67-94.

Juraga, Dubravka. "Nuruddin Farah's Variations on the Theme of an African Dictatorship: Patriarchy, Gender and Political Oppression in Somalia." Emerging Perspectives on Nuruddin Farah, edited by Derek Wright. Africa World P, 2002, pp. 283-308.

Kapteijns, Lidwien. "Nuruddin Farah's Gifts." African Novels in the Classroom, edited by M. J. Hay, Lynne Rienner, 2000, pp. 145-52.

Review of Yesterday, Tomorrow: Voices from the Somali Diaspora. International Journal of African Historical Studies vol. 33, no. 2, 2000, pp. 384-6. DOI: https://doi.org/10.2307/220664.

Kazan, Francesca. "Recalling the Other Third World: Nuruddin Farah's Maps." Emerging Perspectives on Nuruddin Farah, edited by Derek Wright. Africa World P, 2002, pp. 469-94.

Kelly, Hilarie. "A Somali Tragedy of Political and Sexual Confusion: A Critical Analysis of Nuruddin Farah's Maps." Ufahamu vol. 16, no. 2, 1988, pp. 21-37. 
Mari, Lorenzo. "Tabula Rasa and Fiction: Representations of Mogadishu during the Conflict (2002-2011)." Afrika-Raum-Literatur: Fiktionale Geographien/Africa-Space-Literature: Fictional Geographies, edited by Bruno Arich-Gerz, Kira Schmidt \& Antje Ziethen, Gardez!, 2014, pp. 125-49.

Mazrui, Alamin. "Mapping Islam in Farah's Maps." The Marabout and the Muse: New Approaches to Islam in African Literature, edited by Kenneth W. Harrow. Heinemann, 1996, pp. 205-17.

Mazrui, Alamin. "Secrets: The Somali Dispersal and Reinvented Identities." Emerging Perspectives on Nuruddin Farah, edited by Derek Wright. Africa World P, 2002, pp. 615-36.

McDowell, Robert. "Nuruddin Farah." African Writers, edited by C. Brian Cox, Charles Scribner's Sons, 1997, pp. 249-62.

Medugno, Marco. "A Contested Spatiality: The Representation of Mogadishu in Somali Anglophone and Italian Literature." Italian Studies in Southern Africa vol. 31, no. 1, 2018, pp. 110-34.

"The Distinctive Use of the Italian Language in Nuruddin Farah's Late Production." From the European South vol. 3, 2018, pp. 71-84.

Merrington, Peter. "Review of Yesterday, Tomorrow: Voices from the Somali Diaspora, by Nuruddin Farah." The English Academy Review vol. 19, 2002, pp. 109-12.

Mirmotahari, Emad. "Revisiting Farah's From a Crooked Rib." Islam in the Eastern African Novel, by Emad Mirmotahari. Palgrave Macmillan, 2011, pp. 123-39. DOI: https://doi.org/10.1057/9780230119291.

Mnthali, Felix. "Autocracy and the Limits of Identity: A Reading of the Novels of Nuruddin Farah." Emerging Perspectives on Nuruddin Farah, edited by Derek Wright. Africa World P, 2002, pp. 175-96.

Moolla, F. Fiona. "Love in a State of Fear: Reflections on Intimate Relations in Nuruddin Farah's Dictatorship Novels." Journal of the African Literature Association vol. 10, no. 1, 2016, pp. 118-30. DOI: https://doi.org/10.1080 121674736.2016.1199347.

"When Orature Becomes Literature: Somali Oral Poetry and Folk Tales in Somali Novels." Comparative Literature Studies vol. 49, no. 3, 2012, pp. 434-62. DOI: https://doi.org/10.5325/complitstudies.49.3.0434.

Moore, Gerald. "Maps and Mirrors." Emerging Perspectives on Nuruddin Farah, edited by Derek Wright. Africa World P, 2002, pp. 509-20.

Moore, Gerald. "Nomads and Feminists: The Novels of Nuruddin Farah." Emerging Perspectives on Nuruddin Farah, edited by Derek Wright. Africa World P, 2002, pp. 155-74.

Myers, Garth. African Cities: Alternative Visions of Urban Theory and Practice. Zed, 2011. [Large sections of this book consider Farah's representations of Mogadishu.]

Mzali, Ines. "Wars of Representation: Metonymy and Nuruddin Farah's Links." College Literature vol. 37, no. 3, 2010, pp. 84-105. DOI: https://doi.org/10.1353/lit.0.0124.

Naicker, Kamil. "Going to Pieces: Narrative Disintegration in Nuruddin Farah's Crossbones." Social Dynamics vol. 43, no. 1, 2017, pp. 8-18. DOI: https://doi.org/10.1080/02533952.2017.1341089.

Ngaboh-Smart, Francis. Beyond Empire and Nation: Postnational Arguments in the Fiction of Nuruddin Farah and B. Kojo Laing. Rodopi, 2004.

. "Dimensions of Gift-Giving in Nuruddin Farah's Gifts." Emerging Perspectives on Nuruddin Farah, edited by Derek Wright, Africa World Press, 2002, pp. 567-90.

. "Nationalism and the Aporia of National Identity in Farah's Maps." Research in African Literatures vol. 32, no. 3, 2001, pp. 86-102. DOI: https://doi.org/10.1353/ral.2001.0075.

. "Secrets and a New Civic Consciousness." Research in African Literatures vol. 31, no. 1, 2000, pp. 129-36. DOI: https://doi.org/10.1353/ral.2000.0025.

Ngũgĩ wa Thiong'o. "Nuruddin Farah: A Statement of Nomination to the 1998 Neustadt Jury." World Literature Today vol. 72 , no. 4, 1998, p. 716. DOI: https://doi.org/10.2307/40154258.

Ntalindwa, Raymond. "Linkages of History in the Narrative of Close Sesame." Journal of African Cultural Studies vol. 12, no. 2, 1999, pp. 187-202. DOI: https://doi.org/10.1080/13696819908717849.

"Nationalism and the East African Writer: The Position of Nuruddin Farah." Ufahamu: A Journal of African Studies vol. 25, no. 3, 1997, pp. 67-85.

Odeh, Tayseer Abu. "The Pleasures and Pitfalls of Exile and Counterpoint in Farah's Maps." Arab Studies Quarterly vol. 40, no. 2, 2018, pp. 134-54. DOI: https://doi.org/10.13169/arabstudquar.40.2.0134.

Okonkwo, Juliet. "Literature and Politics in Somalia: The Case of Nuruddin Farah." Africa Today vol. 32, no. 3, 1985, pp. 57-65. 
"The Novelist as Artist: The Case of Nuruddin Farah." Commonwealth Novel in English vol. 5, no. 1, 1992, pp. 46-58.

. "Nuruddin Farah and the Changing Roles of Women." World Literature Today vol. 58, no. 2, 1984, pp. 215-21. DOI: https://doi.org/10.2307/40139950.

Pajalich, Armando. "Allegorizing Terror: A Comparative Study of Novels by Farah and Soyinka." Emerging Perspectives on Nuruddin Farah, edited by Derek Wright. Africa World P, 2002, pp. 309-30.

Petersen, Kirsten Holst. "Charity Wounds Him Who Receives: Nuruddin Farah's Gifts." Emerging Perspectives on Nuruddin Farah, edited by Derek Wright. Africa World Press, 2002, pp. 591-610.

"The Personal and the Political: The Case of Nuruddin Farah." Emerging Perspectives on Nuruddin Farah, edited by Derek Wright. Africa World P, 2002, pp. 243-52.

Phillips, Maggi. “To a Room of Their Own: Structure and Shadow in Nuruddin Farah's Sardines." Emerging Perspectives on Nuruddin Farah, edited by Derek Wright. Africa World P, 2002, pp. 381-98.

."The View from a Mosque of Words: Nuruddin Farah's Close Sesame and The Holy Qur'an." The Marabout and the Muse: New Approaches to Islam in African Literature, edited by Kenneth W. Harrow. Heinemann, 1996, pp. 191-204.

Ruggiero, Rossana. "Maps: The Faint Borderland of a Warrior of Words." Emerging Perspectives on Nuruddin Farah, edited by Derek Wright. Africa World P, 2002, pp. 559-66.

Rushdie, Salman. "Nuruddin Farah." Imaginary Homelands: Essays and Criticism, 1981-90, by Salman Rushdie. Granta, 1991, pp. 201-2.

Samatar, Said S. "Are There Secrets in Secrets?" Research in African Literatures vol. 31, no. 1, 2000, pp. 137-43. DOI: https://doi.org/10.1353/ral.2000.0033.

Sasic, Borislava. "Nuruddin Farah's Sardines: The Construction of a Somali Novel on the Intersection of Transcultural Intertextuality." Across the Lines: Intertextuality and Transcultural Communication in the New Literatures in English, edited by Wolfgang Klooss. Rokop, 1998, pp. 167-76.

Schraeder, Peter. "The Novels of Nuruddin Farah: The Sociopolitical Evolution of a Somali Writer." Emerging Perspectives on Nuruddin Farah, edited by Derek Wright, Africa World P, 2002, pp. 197-214.

Sparrow, Fiona. "Telling the Story Yet Again: Oral Traditions in Nuruddin Farah's Fiction." Journal of Commonwealth Literature vol. 24, no. 1, 1989, pp. 164-72. DOI: https://doi.org/10.1177\%2F002198948902400114.

Stratton, Florence. "The Novels of Nuruddin Farah." Emerging Perspectives on Nuruddin Farah, edited by Derek Wright. Africa World P, 2002, pp. 131-54.

Sugnet, Charles. "Nuruddin Farah's Maps: Deterritorialization and 'The Postmodern." Emerging Perspectives on Nuruddin Farah, edited by Derek Wright. Africa World P, 2002, pp. 521-44.

Turfan, Barbara. "Opposing Dictatorship: A Comment on Nuruddin Farah's Variations on the Theme of an African Dictatorship." Emerging Perspectives on Nuruddin Farah, edited by Derek Wright. Africa World P, 2002, pp. 26581.

Vivan, Itala. "Nuruddin Farah's Beautiful Mat and Its Italian Plot.” World Literature Today vol. 72, no. 4, 1998, pp. 786-90. DOI: https://doi.org/10.2307/40154271.

Waberi, Abdourahman A. “Organic Metaphor in Two Novels by Nuruddin Farah.” World Literature Today vol. 72 , no. 4, 1998, pp. 775-80. DOI: https://doi.org/10.2307/40154269.

Walmsley, Anne. "Nuruddin Farah and Somalia." Index on Censorship vol. 2, 1981, pp. 17-19. DOI: https://doi.org/10. 1080\%2F03064228108533178.

Williams, R. John. “Doing History': Nuruddin Farah's Sweet and Sour Milk, Subaltern Studies, and the Postcolonial Trajectory of Silence." Research in African Literatures vol. 37, no. 4, 2006, pp. 161-76. DOI: https://doi.org/10.1353/ ral.2006.0103.

Woods, Tim. "Giving and Receiving: Nuruddin Farah's Gifts, or, the Postcolonial Logic of Third World Aid." Journal of Commonwealth Literature vol. 38, no. 1, 2003, pp. 91-112. DOI: https://doi.org/10.1177/0021989404381008.

Wright, Derek. "Fabling the Feminine in Nuruddin Farah's Novels." Essays on African Writing. Volume 1: A Reevaluation, edited by Abdulrazak Gurnah. Heinemann, 1993, pp. 70-87.

“Going to Meet the General: Deeriye's Death in Nuruddin Farah's Close Sesame." Journal of Commonwealth Literature vol. 29, no. 2, 1994, pp. 23-30. DOI: https://doi.org/10.1177/002198949402900204. "History's Illuminated Prints: Negative Power in Nuruddin Farah's Close Sesame." World Literature Today vol. 72, no. 4, 1998, pp. 733-38. DOI: https://doi.org/10.2307/40154263. 
. "Mapping Farah's Fiction: The Postmodern Landscapes." Emerging Perspectives on Nuruddin Farah, edited by Derek Wright. Africa World P, 2002, pp. 95-130.

. "Misogyny Misconstrued: A Naked Needle." Emerging Perspectives on Nuruddin Farah, edited by Derek Wright. Africa World P, 2002, pp. 253-64.

. "Nations as Fictions: Postmodernism in the Novels of Nuruddin Farah." Critique vol. 38, no. 3, 1997, pp. 193-204. DOI: https://doi.org/10.1080/00111619.1997.10543175.

. "Orality and Power in Sweet and Sour Milk." Emerging Perspectives on Nuruddin Farah, edited by Derek Wright. Africa World P, 2002, pp. 345-58.

. "Private and Public Secrets: Family and State in Nuruddin Farah's Secrets." The Journal of Commonwealth Literature vol. 39, no. 7, 2004, pp. 7-27. DOI: https://doi.org/10.1177/0021989404044733.

. "Requiems for Revolutions: Race-Sex Archetypes in Two African Novels." Modern Fiction Studies vol. 35, no. 1, 1989, pp. 55-68. DOI: https://doi.org/10.1353/mfs.0.0472. 